\title{
ANTHELMINTIC EFFICACY OF ORALLY ADMINISTERED IVERMECTIN AGAINST NEMATODES IN THE MOUFFLON (Ovis musimon)
}

\author{
J. LAMKA ${ }^{1}$, R. PESKKA ${ }^{1}$, E. KULICHOVÁ ${ }^{1}$, J. UREŠOVÁ ${ }^{1}$, M. VONDŘEJC ${ }^{2}$ \\ ${ }^{1}$ Department of Pharmacology and Toxicology, Faculty of Pharmacy, \\ Charles University Hradec Králové \\ ${ }^{2}$ Forestry Company, Opočno \\ Received September 15, 1995 \\ Accepted September 24, 1996
}

\begin{abstract}
Lamka J., R. Peška, E. Kulichová, J. Urešová, M. Vondřejc: Anthelmintic Efficacy of Orally Administered Ivermectin against Nematodes in the Moufflon (Ovis musimon). Acta vet. Brno, 1996, 65:225-228.

The aim of the experiment was to study the efficacy of ivermectin against lung and gastrointestinal nematodes in the moufflon. The pharmaceutical was administered orally on 6 consecutive days at a dose of $415 \mathrm{mg} . \mathrm{kg}^{-1}$ per day to each of 19 moufflons infected naturally with Müllerius capillaris, Chabertia ovina and Nematodirus spp. Their fecal samples collected before, during and after ivermectin administration were examined. On days 14,21 and 28 after the treatment was finished, 2 animals were shot, respectively. Their lungs, duodena, colon and ceaca were necropsied for the parasites. Parasitological examination of the organs proved a good helminthicidal efficacy of the preparation including that against the adult Müllerius capillaris. Based on examination of pooled fecal samples it was shown that ivermectin rapidly stopped also the elimination of infective forms (eggs and larvae) of the helminths. The drug was readily consumed and well tolerated. The animals did not show signs of side effects.
\end{abstract}

Müllerius capillaris, Chabertia ovina, Nematodirus spp., necropsy, GIT, lungs

The most common parasites found in the moufflon herds reared in the Czech Republic are Müllerius capillaris, Neostrongylus linearis, Chabertia ovina, Oesophagostomum venulosum, Trichuris spp. and Capillaria spp. (Pá v et al. 1981; Kotrlá et al. 1984).

Helminthoses caused by these species in regions with high concentrations of game animals (especially in game parks) have often very high prevalence and intensity of infections (InIn).

At present, a variety of measures may be employed to combat them, including pharmacotherapy. Among the most frequently employed drugs are those with imidazole structure. This group of drugs in recommended doses is effective against gastrointestinal and lung nematodes, such as thiabendazole (Kalivoda and Chroust 1971), thiabendazole, mebendazole, oxfendazole (Chroust 1982), and luxabendazole (Chroust 1992). Among the helminthoses, mülleriosis is difficult to treat because of localization of adult forms in nodules in the lung parenchyma.

The modules are mostly surrounded by changed parenchyma encapsulating the adult worms with a hardly permeable structure. Due to its lipophilic properties (C a mpbell 1989) ivermectin is the drug of the choice for therapy. However, no data are so far available on its use in moufflon. We therefore designed the present study to investigate the tolerance of ivermectin in this game species during a prolonged oral therapy, further to test its therapeutical efficacy against helminthoses in moufflons with special attention paid to mülleriosis.

\section{Materials and Methods}

Randomly selected moufflons $(n=19)$ from a population living in the game park Opočno was placed in an enclosed area of 5 hectares. Prior to treatment, all animals were coprologically examined. 
Table 1

Characteristics of animals used for helmintological examination

\begin{tabular}{|c|c|c|c|c|}
\hline Animal & Sex & $\begin{array}{c}\text { Age of } \\
\text { animal } \\
\text { (months) }\end{array}$ & $\begin{array}{c}\text { Day of } \\
\text { experiment }\end{array}$ & $\begin{array}{c}\text { Total body } \\
\text { mass } \\
(\mathrm{kg})\end{array}$ \\
\hline A & f & 22 & 21 & 31 \\
B & f & 11 & 21 & 14 \\
C & m & 22 & 28 & 36 \\
D & f & 11 & 28 & 18 \\
E & $\mathrm{m}$ & 11 & 35 & 34 \\
F & $\mathrm{m}$ & 35 & 21 \\
\hline
\end{tabular}

Ivermectin administration: The pharmaceutical Cermix premix for hoofed game (Biopharm - VÚBVL, Jilové u Prahy) was mixed with barley groats, and this medicated feed was offered at libitum for 6 consecutive days. From the total feed consumption, an average daily dose per animal was calculated, and it amounted to $0.415 \mathrm{mg}^{-\mathrm{kg}^{-1}}$.

Necropsy was carried out on days 21,28 and 35, always in two randomly shot animals (A-F, see Table 1). Complete helminthological necropsy was carried out in each animal.

Fresh fecal samples were collected from at least 15 animals, examined both quantitatively and qualitatively for parasites (Dunn 1978). Feces from necropsied animals were collected in the distal portion of the colon and examined in the same way. The lungs were evaluated macroscopically, and then samples of the tissue were examined for the presence of $M$. capillaris larvae. The total number of samples was given by the extent of pathological changes detected in individual animals (A, B - 3 samples, $\mathrm{C}-5$ samples, D- 6 samples, E, F- 8 samples). The gastrointestinal tract (abomasum, small and large intestines, caeca) was examined for adult nematodes in each animal.

Table 2

Coprological findings in pooled fecal samples (6 days treatment)

\begin{tabular}{|c|c|c|c|}
\hline $\begin{array}{c}\text { Day of } \\
\text { experiment }\end{array}$ & $\begin{array}{c}\text { Müllerius capillaris } \\
\text { (LPG) } \\
\mathrm{n}=10\end{array}$ & $\begin{array}{c}\text { Chabertia ovina } \\
\text { (EPG) } \\
\mathrm{n}=3\end{array}$ & $\begin{array}{c}\text { Nematodirus spp. } \\
\text { (EPG) } \\
\mathrm{n}=3\end{array}$ \\
\hline-4 & 146 & 50 & 8 \\
-2 & 153 & 33 & 8 \\
1 & 54 & 58 & 17 \\
2 & 43 & 0 & 8 \\
3 & 47 & 0 & 0 \\
4 & 40 & 0 & 0 \\
5 & 37 & 0 & 0 \\
6 & 22 & 0 & 0 \\
7 & 49 & 0 & 0 \\
14 & 0 & 0 & 0 \\
21 & 0 & 0 & 0 \\
28 & 0 & 0 & 0 \\
35 & 0 & 0 & 0 \\
\hline
\end{tabular}

$\mathrm{n}=$ Number of examinations

- Day of experiment $=$ Findings before ivermectin administration

$\mathrm{LPG}=$ Larvae per gram, EPG $=$ Eggs per gram 


\section{Results}

Coprological examinations of pooled samples: Before treatment, larvae of $M$. capillaris, eggs of Ch. ovina and Nematodirus spp. were found. Collections of fecal samples and the findings are given in Table 2.

EPG and LPG values found before treatment decreased with duration of ivermectin medication. A rapid decrease was found in gastrointestinal nematodes so that as soon as on day 2 of treatment (Chabertia) or day 3 (Nematodirus) the coprological findings became negative. The decrease in LPG of M. capillaris was slowlier but regular until day 6, on day 7 there was an increase but from day 14 onwards the findings became negative.

Parasitological findings in the lungs: Macroscopical examination showed symptoms of mülleriosis of different extent in all 6 necropsied animals. Larvoscopical examination after the treatment became negative.

Helminthological findings in gastrointestinal tract: Based on coprological examinations, abomasum, small and large intestines an caeca were nacropsied. No adult nematodes were found in any of the animals.

\section{Discussion}

Game park type of moufflon husbandry in which our experiment was carried out, presents a situation typical of similar rearing systems in the Czech Republic from the helminthological point of view. During the autumn months of 1994, 18 samples of gastrointestinal organs and lungs were examined, and repeatedly mülleriosis, chabertiosis and nematodirosis, in single cases also capillariosis and trichostrongylosis were diagnosed. The most serious finding in terms of its prevalence was mülleriosis.

In regularly occurring lung nodules LPG values of $180-1150$ were found by cultivation, in feces of these animals it reached 35-305. The above-mentioned findings prompted us to employ ivermectin on a long-time basis and evaluate the results of such treatment. The presented data are the results of the pilot study.

Consumption of the medicated feed in the course of the experiment was very good. During the treatment period, cold weather and snow prevailed, and the animals readily ate all the offered feed. No adverse effects were observed.

Results of the coprological examinations from the pre-treatment period, the course of treatment and the post - treatment period document a rapid and complex effect of the drug on the parasites. The EPG values, even if they were low prior to treatment, became negative in the course of medication. Similar situation was observed with $M$. capillaris with a slower decrease of the original values.

Results of helminthological necropsies characterize in more detail the therapeutic effects of ivermectin. Its helminthocidal effect was shown in shot animals as soon as 14 days after the treatment was finished, and repeatedly after further 7 and 14 days. The results are valuable especially because prevalence of mülleriosis was $100 \%$ before the treatment, and considering the extent of pathological changes in the lungs, InIn had also to be high. In cases that showed extensive changes, cultivation was carried out from multiple sites of the changed tissue. Helminthological necropsy of gastrointestinal tract of all 6 animals revealed freedom from adult nematodes.

The results of our pilot study show that treatment of moufflons with ivermectin is highly efficient against several nematodes in contrast to other drugs (Chroust 1982, 1985). The animals tolerate the drug well. Ivermectin can therefore be considered a drug of first choice in treatment of moufflon flocks. 


\section{Anthelmintická účinnost perorálně podaného ivermektinu proti nematodům mufloní zvěře (Ovis musimon)}

Nematoda patří mezi nejběžnější původce parazitárních onemocnění mufloní zvěře v České republice. $\mathrm{K}$ farmakoterapii jsou využitelná mnohá léčiva dominantně imidazolové struktury. Mezi nová léčiva odlišné struktury vytipovaná pro spárkatou zvěř patří ivermektin. Cílem této studie bylo ověrit účinnost ivermektinu proti nematodám plic a trávicího traktu mufloní zvěře.

Studie byla uskutečněna na 19 muflonech v malé oboře. Ivermektin byl podáván 6 dnů (denní dávka $0,415 \mathrm{mg} / \mathrm{kg}$ živé hmotnosti) přirozeně infikovaným muflonům (Müllerius capillaris, Chabertia ovina, Nematodirus spp.). Byly vyšetřeny vzorky směsného trusu sebrané před podáním ivermektinu, $v$ době léčby a po jejím ukončení. 21., 28. a 35. den po ukončení léčby byla postupně odlovena vždy 2 zviŕata, jejich plíce, tenké, slepé a tlusté střevo i trus byly helmintologicky vyšetřeny. Na základě výsledků vyšetření směsných vzorků trusu bylo prokázáno, že ivermektin rychle zastavil vylučování infekčních stádií (larev, vajíček) přitomných helmintů. Parazitologickými vyšetřeními orgánů odlovených zviŕă byla prokázána helmintocidní účinnost léčiva včetně účinnosti proti dospělcům Müllerius capillaris. Léčivo bylo zviŕaty ochotně prijímáno a snášeno bez vedlejších účinků.

\section{Acknowledgement}

The authors estend their thanks to Ms. J. Marek and Mrs. J. Uhrová for technical assistance.

\section{References}

CAMPBELL, W. C. 1989: Ivermectin and abamectin. New York, Springer-Verlag, pp. 7-8

CHROUST, K. 1982: Výsledky sledování účinnosti některých širokospektrých anthelmintik u spárkaté zvěře. Folia venatoria 12:209-215

CHROUST, K. 1985: Sledování anthelmintické účinnosti fenbendazolu proti plicním a gastrointestinálním hlísticím spárkaté zvěře. Sborník vědeckých prací ÚSVÚ Praha 13:98-103

CHROUST, K. 1992: Rozšiření, dynamika, patogenita a boj proti ekonomicky významným plicním a gastrointestinálním helmintózám domácích a volně žijících přežvýkavců. Thesis, University of Veterinary Medicine Brno, pp. 294-304

DUNN, A. M. 1978: Veterinary helmintology. London, W. Heineman Medical Books, pp. 37-86 and 297-301

KALIVODA, J. CHROUST, K. 1971: Anthelmintic effectiveness of Thibenzole administered in pelleted feeds to fallow deer and moufflon. Acta vet. Brno 40:453-462

KOTRLÁ, B., ČERNÝ, V., KOTRLÝ, A., MINÁŘ, J., RYŠAVÝ, B., ŠEBEK, Z. 1984: Parazitózy zvěře. Prague, Academia, pp. 157-162

PÁV, J., KOŻUŠNIK, Z., MATOUŠEK, Z., VANČURA, V., ZAJÍČEK, D. 1981: Choroby lovné zvěře. Prague, SZN, pp. 167-185

Address for correspondence:

Doc. RNDr. J. Lamka, CSc.

Department of Pharmacology and Toxicology

Faculty of Pharmacy, Charles University

Heyrovského 1203

CZ-50005 Hradec Králové

Czech Republic 